\title{
The unfavorable role of titanium particles released from dental implants
}

\author{
Zilan Zhou ${ }^{1,2 *}$, Quan Shi ${ }^{3 *}$, Jie Wang1,2, Xiaohang Chen ${ }^{1,2}$, Yujia Hao ${ }^{1,2}$, Yuan Zhang ${ }^{1,2}$, Xing Wang ${ }^{1,2}$ \\ 1. Shanxi Medical University School and Hospital of Stomatology, Taiyuan 030001, China. \\ 2. Shanxi Province Key Laboratory of Oral Diseases Prevention and New Materials, Taiyuan 030001, China. \\ 3. Institute of Stomatology, First Medical Center, Chinese PLA General Hospital, Beijing, China. \\ * These authors have contributed equally to this work. \\ $\square$ Corresponding author: Xing Wang, Shanxi Medical University School and Hospital of Stomatology, Xinjian south road 63\#, Taiyuan 030001, China; Tel: +86 \\ 351469 0307; Fax: +86 351469 0307; Email: kqwx100@163.com
}

(c) The author(s). This is an open access article distributed under the terms of the Creative Commons Attribution License (https://creativecommons.org/licenses/by/4.0/). See http://ivyspring.com/terms for full terms and conditions.

Received: 2020.11.25; Accepted: 2021.02.10; Published: 2021.03.10

\begin{abstract}
Titanium is considered to be a metal material with the best biological safety. Studies have proved that the titanium implanted in the bone continuously releases titanium particles ( $\mathrm{Ti}$ particles), significantly increasing the total titanium content in human body. Generally, Ti particles are released slowly without causing a systemic immune response. However, the continuous increased local concentration may result in damage to the intraepithelial homeostasis, aggravation of inflammatory reaction in the surrounding tissues, bone resorption and implant detachment. They also migrate with blood flow and aggregate in the distal organ. The release of $\mathrm{Ti}$ particles is affected by the score of the implant surface structure, microenvironment wear and corrosion, medical operation wear, and so on, but the specific mechanism is not clear. Thus, it difficult to prevent the release completely. This paper reviews the causes of the $\mathrm{Ti}$ particles formation, the damage to the surrounding tissue, and its mechanism, in particular, methods for reducing the release and toxicity of the Ti particles.
\end{abstract}

Key words: Titanium Particles, Chemical Corrosion, Surface Wear, Surface Modification.

\section{Introduction}

Dental caries, trauma, and other tooth loss causes seriously affect the quality of life of patients. In the mid-1950s, Branemark and Albrektsson first used high-purity titanium as an implant material and put forward the classical osseointegration theory (titanium direct contact with bone tissue without fibrous tissue intervention) [1]. Nowadays, titanium implants have been utilized in a higher frequency to replace missing teeth, because it provides a long-term masticatory function and an excellent aesthetic effect [2]. The number of dental patients increases by 5 million each year worldwide [3]. Moreover, titanium is currently considered the first-rate metal material with biological safety, and almost 1,000 tons of titanium have been applied clinically in different forms, such as artificial joints, cochlear implants, and heart valves, every year [4].
In a healthy human body, titanium content should not exceed $15 \mathrm{mg}$ per $70 \mathrm{~kg}$ body weight. Studied have demonstrated that titanium implants in bones could continuously release titanium particles (Ti particles) [5, 6], which may last from a few hours to several months. Generally, these particles are highly insoluble and difficult to eliminate from the body, usually distributed in the hard and soft tissue around the implant [7]. The release of Ti particles is often neglected because the release rate is relatively slow without induction of a systemic immune response [8]. Once the concentration of local $\mathrm{Ti}$ particles is excessive, it will destroy oral intraepithelial homeostasis, aggravate inflammation in surrounding tissues, and lead to a dynamic imbalance of osteoblasts and osteoclasts $[9,10]$. Furthermore, the released $\mathrm{Ti}$ particles are not confined in the tissue 
around the implant, even migrate with the blood, and gradually accumulate in the distal organs [6, 11-13], causing systemic allergies and allergic reactions.

At present, various techniques have been used to increase surface roughness and hydrophilicity, such as sandblasting acid etching (SLA), plasma spraying, electrophoretic deposition, and other methods [4]. However, none of them could thoroughly prevent the release of $\mathrm{Ti}$ particles from the implant. The influencing factors of the release are related to the surface structure of the implant, micro-environment wear and corrosion, medical surgery wear and so on. This paper reviews the cause of Ti particles released from dental implants, the mechanisms and the damage to the surrounding cells and tissues, as well as methods to reduce the release and toxicity of $\mathrm{Ti}$ particles.

\section{Ti particles}

\subsection{Definition}

Titanium is generally accepted to be the preferred metal material in dental implants. However, once exposed to air, the titanium implant surface spontaneously forms a stable titanium oxide layer. The corrosion resistance of implant comes from the oxide layer that protects the implant from the surrounding tissue. Various factors destroy the titanium oxide layer [14], releasing Ti particles from the surface. Those particles are not entirely bioinert material, and are distributed in cells and tissues. It has been reported that the presence of Ti particles may be harmful and trigger a series of biological reactions (Table 1, Table 2) [15-17].

Ti particles have multiple shapes, such as round and slender [2], with sizes of $15 \mathrm{~nm}$ to $45 \mu \mathrm{m}$. Nanoparticles and micron $\mathrm{Ti}$ particles are more common than millimeter particles $[18,19]$. It has been reported that the size of Ti particles decreases with the increase of distance from the titanium implant $[20,21]$.

Tables 1. In vitro studies related to titanium particles

\begin{tabular}{|c|c|c|c|}
\hline Author (Year) & In vitro & Titanium particles size & Conclusion \\
\hline $\begin{array}{l}\text { William J. Maloney, } \\
\text { M.D et al. (1993) }\end{array}$ & $\begin{array}{l}\text { Bovine Synovial } \\
\text { Fibroblasts }\end{array}$ & $0.1-10 \mathrm{~mm}$ & $\begin{array}{l}\text { Titanium has no obvious effect on hexosaminidase at any concentration. The } \\
\text { morphological response of fibroblasts to titanium includes membrane wrinkling and } \\
\text { filopodia expansion. }\end{array}$ \\
\hline Senna et al. (2015) & Bovine ribs & $10 \mathrm{~nm}-20 \mu \mathrm{m}$ & $\begin{array}{l}\text { The shear force during insertion changes the surface of the dental implant. Ti particles } \\
\text { are generated at the bone-implant interface, especially around the surface. }\end{array}$ \\
\hline $\begin{array}{l}\text { Eemeli Jämsen et al. } \\
\text { (2019) }\end{array}$ & $\begin{array}{l}\text { Mouse Bone Marrow } \\
\text { Macrophages (mBMMs) }\end{array}$ & $0.1-7.5 \mu \mathrm{m}$ & $\begin{array}{l}\text { The different states of macrophages (young and old) are not affected by Ti particles, } \\
\text { but macrophage polarization affects the inflammatory response induced by Ti } \\
\text { particles. }\end{array}$ \\
\hline $\begin{array}{l}\text { Wen Wu et al. } \\
\text { (2019) }\end{array}$ & Fibroblasts & $1-3 \mathrm{~mm}$ & $\begin{array}{l}\text { T particles disrupt the autophagy of fibroblasts in the interface membrane, up-regulate } \\
\text { the expression of ADAM10, and then promote the release of CX3CL1, and ultimately } \\
\text { promote the chemotactic migration and recruitment of monocytes/macrophages. }\end{array}$ \\
\hline $\begin{array}{l}\text { Ning Song et al. } \\
\text { (2019) }\end{array}$ & $\begin{array}{l}\text { Trigeminal Root Ganglion } \\
\text { (TRG) Neurons }\end{array}$ & $<5 \mathrm{~mm}$ & $\begin{array}{l}\text { Ti particles might alter the electrophysiological properties of voltage-gated potassium } \\
\text { channels (VGPCs) on TRG neurons. }\end{array}$ \\
\hline
\end{tabular}

Table 2. The size, distribution, detection methods and conclusions of titanium particles in related studies in vivo

\begin{tabular}{|c|c|c|c|c|c|}
\hline Author (Year) & Implant surface & Titanium size & Distribution area & Detection methods & Conclusion \\
\hline $\begin{array}{l}\text { Schliephake et al. } \\
\text { (1993) }\end{array}$ & Machined & $\begin{array}{l}\text { Round } \\
\text { size }(15 \times 30 \mu \mathrm{m})\end{array}$ & $\begin{array}{l}\text { Lung, liver, } \\
\text { kidneys(5months) }\end{array}$ & $\begin{array}{l}\text { SEM, BSE probe, } \\
\text { EDS, FASS }\end{array}$ & $\begin{array}{l}\text { The wear produces Ti particles, which are distributed } \\
\text { between the bone and the implant. It is also taken up by cells } \\
\text { and transferred to remote organs. }\end{array}$ \\
\hline $\begin{array}{l}\text { Tanaka et al. } \\
(2000)\end{array}$ & TPS & $1.8-3.2 \mu \mathrm{m}$ & Bone surface & $\begin{array}{l}\text { LM, SEM, X-ray, } \\
\text { TEM, electron } \\
\text { diffraction }\end{array}$ & $\begin{array}{l}\text { It is necessary to study the impact of Ti particles on the } \\
\text { human body. }\end{array}$ \\
\hline $\begin{array}{l}\text { Meyer et al. } \\
(2006)\end{array}$ & $\begin{array}{l}\text { Sandblasted, } \\
\text { TPS, Machined, } \\
\text { Acid-etched }\end{array}$ & $20 \mathrm{~nm}$ & Crestal & SEM, EDS & $\begin{array}{l}\text { The wear of titanium near the plasma sprayed surface is the } \\
\text { highest, followed by the acid-etched and smooth grating } \\
\text { surface that has been sandblasted. }\end{array}$ \\
\hline $\begin{array}{l}\text { Flatebo et al. } \\
(2011)\end{array}$ & Anodized & $100-5000 \mathrm{~nm}$ & $\begin{array}{l}\text { Surface of oral } \\
\text { mucosa }\end{array}$ & $\begin{array}{l}\text { HR-ODM, SEM, } \\
\text { LA-ICP-MS, EDS }\end{array}$ & $\begin{array}{l}\text { The combination of LA-ICP-MS (identifying chemical } \\
\text { components) and HR-ODM (providing a histological } \\
\text { reference) seems to be an effective method for detecting } \\
\text { particles in oral tissues. }\end{array}$ \\
\hline $\begin{array}{l}\text { Xiuli He et al. } \\
\text { (2016) }\end{array}$ & & $0.5-40 \mu \mathrm{m}$ & $\begin{array}{l}\text { Tissue around } \\
\text { implant }\end{array}$ & $\begin{array}{l}\text { SEM-EDX, light } \\
\text { microscopy }\end{array}$ & $\begin{array}{l}\text { Confirm that the Ti particles are released into the tissues } \\
\text { around the human jaw. }\end{array}$ \\
\hline $\begin{array}{l}\text { Mattias } \\
\text { Pettersson et al. } \\
(2017)\end{array}$ & & & $\begin{array}{l}\text { Tissue around } \\
\text { implant }\end{array}$ & SEM, ICP-AES & $\begin{array}{l}\text { The surface structure of the implant is important for the } \\
\text { amount of Ti particles released, while the total area and } \\
\text { diameter of the implant are not so important. }\end{array}$ \\
\hline
\end{tabular}




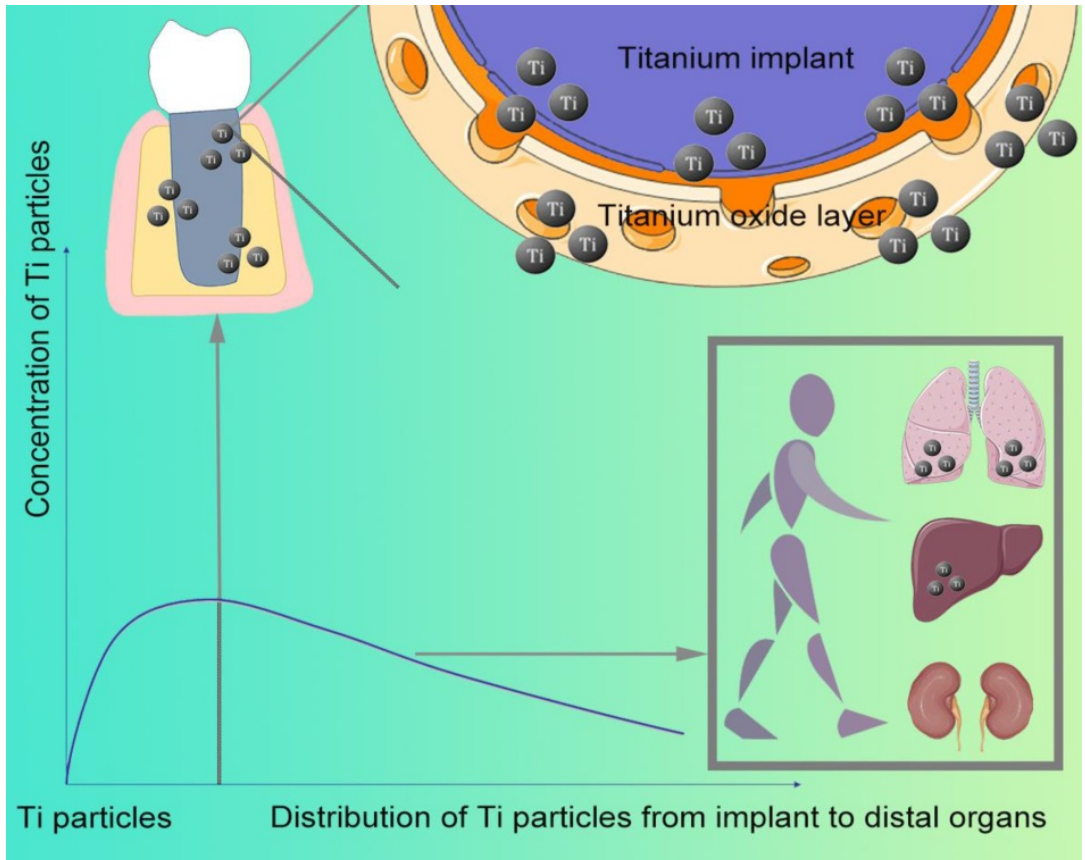

Figure 1. The relationship between Ti particle distribution and concentration

\subsection{Distribution}

After implant placement, Ti particles can be detected on the bone surface and soft tissues around the jaw implant even a few hours. The concentration of Ti particles distributed in the human body is related to the implant distance (Figure 1)-the closer to the implant, the higher the concentration [7]. Compared with implants without inflammation, a higher concentration of Ti particles can be detected at the inflammation site of implant [2]. Moreover, released from the implant, they enter the blood and migrate to multiple organs throughout the body, which can be found in the submandibular and cervical lymph nodes [6], as well as lung, kidney, and liver (Figure 1).

\subsection{Detection methods}

Exfoliative cytology is a simple, non-invasive, well-tolerated diagnostic technique [22]. Cell samples are collected by rotating a microbrush over the surface of the mucosa, and the concentration of Ti particles is measured microchemically using an inductively coupled plasma-mass spectrophotometry (ICP-MS) $[23,24]$. In addition to detect the Ti particles released from the implant surface, oral exfoliation cytology is a tool for detecting metal particles in the cells that shed mucosa around implants and monitoring dental implant corrosion [25]. Laser ablation inductively coupled plasma mass spectroscopy (LA-ICP-MS) is a new technique for determining elements in titanium implants and enable to quantitatively analyze tissue blocks or thin slices placed on different bases, showing the content of resultant two-dimensional map and distribution of elements in the sample. Sajnóg et al. used the LA-ICP-MS to examine the oral mucosa samples around the titanium implants, and revealed that high content of $\mathrm{Ti}$ particles is derived from implants [26]. Swiatkowska et al. suggested to use the concentration of Ti particles in the blood as a biomarker for implant wear with high-resolution instruments [27]. Various analytical methods have been used in labs, but the indication of implant health still remains controversial.

\section{Cause of release}

Chemical corrosion and Surface wear are two main reasons for the release of $\mathrm{Ti}$ particles from implants (Figure 2) [28, 31].

\subsection{Chemical corrosion}

Chemical corrosion is inevitable for almost all the metal implants currently. Williams et al. found that all metals, whether precious or passivated, slowly release metal ions and particles from the surface after long implantation into the human body [32]. Sarmiento-González et al. first reported that in the absence of wear and tear [33], partial surface damage of titanium oxide film occurred after implantation for 12 months or longer [34]. The content of Ti particles increases in the blood, leading to accumulation in organs. The release in the surrounding tissues is attributed to different temperatures of the oral environment, saliva $\mathrm{pH}$. Moreover, bacterial circulation erodes the titanium oxide layer of implant during long-term use [35]. 


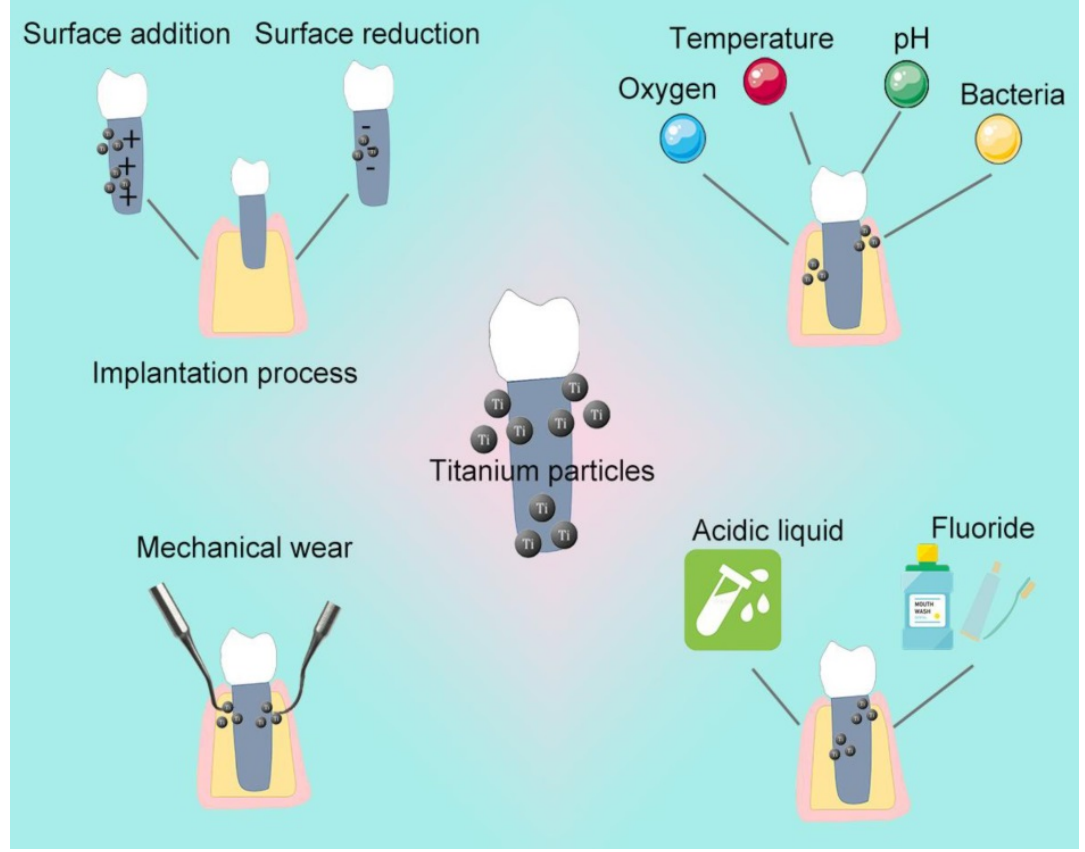

Figure 2. Grounds for the release of Ti particles

Saliva acting as a weak electrolyte, simulates an electrochemical cell in the oral cavity, forms a potential difference, and promotes dissolution of the titanium oxide layer. Hjalmarsson et al. reported that the implant surface becomes rough after contact with saliva [36]. Further electrochemical corrosion of titanium and its alloys causes crevice corrosion, and finally releases of $\mathrm{Ti}$ particles [37, 38]. Infections, drugs, food, periodontitis, smoking, and systemic diseases can reduce the normal saliva $\mathrm{pH}$ of 6.3-7.0 to $<6.0[39,40]$. Acidic environment destroys the surface oxidation layer on the implant film, erodes the surface, and finally lead to releases Ti particles even without wear [41-43]. Gil et al. observed the microstructure of different dental materials before and after the corrosion process, and found that mechanical load significantly reduces the corrosion resistance of titanium [44]. The metal difference between the implant and the superstructure also produces a potential difference, causing gaps, pitting, electrical corrosion, and finally, releasing of $\mathrm{Ti}$ particles from implant [45].

Chemical methods reduce bacterial adhesion and eliminate bacterial toxins or byproducts on the implant surface during routine maintenance of implant. However, some daily used drugs have been proved to corrode the surface, causing release of $\mathrm{Ti}$ particles. Wheelis et al. found that various oral commonly used drugs, such as citric acid, tetracycline, sodium fluoride can cause different degrees of corrosion on the implant surface [46]. Acidic solution $(\mathrm{pH}<3)$ or high fluoride concentration $(>0.2 \%)$ of the above drug mentioned can destroy the oxide film on the surface in a short time, and the $\mathrm{Ti}$ particles released [47-53]. Moreover, fluoride, often added in toothpastes and gels, reduces the corrosion resistance of metal implants [54], destroy the titanium oxide layer, and promotes its dissolution in the oral electrolysis environment [47].

\subsection{Surface wear}

Friction between the bone tissue and the implant generates mechanical retention force during the implantation process, manifesting as microfracture and compression on the bone tissue side [55]. Stress concentration on the implant surface destroys the titanium oxide layer on the body of implant and wares the cover, then releases the Ti particles. Almost all implant implantation processes involve the release associated with implant torque, implant surface roughness [5], surface topography [56], and titanium oxide layer density.

Clinicians use physical instruments, chemical reagents, and lasers to periodically remove proliferating bacteria and their harmful products from the contaminated implant surface [57]. Sirinirund et al. found that metal instruments for cleaning the titanium surface can change the finished morphology of titanium surface and induce Ti particles to fall off the surface [58]. Metal instruments such as metal curettes and scalers do irreversible damage to the implant [59-64], which may change its original surface morphology, result in chemical changes, and release Ti particles. Augthun et al. also found that after using a curette for 60 seconds, the original surface of implant thread edge became rough [63]. 


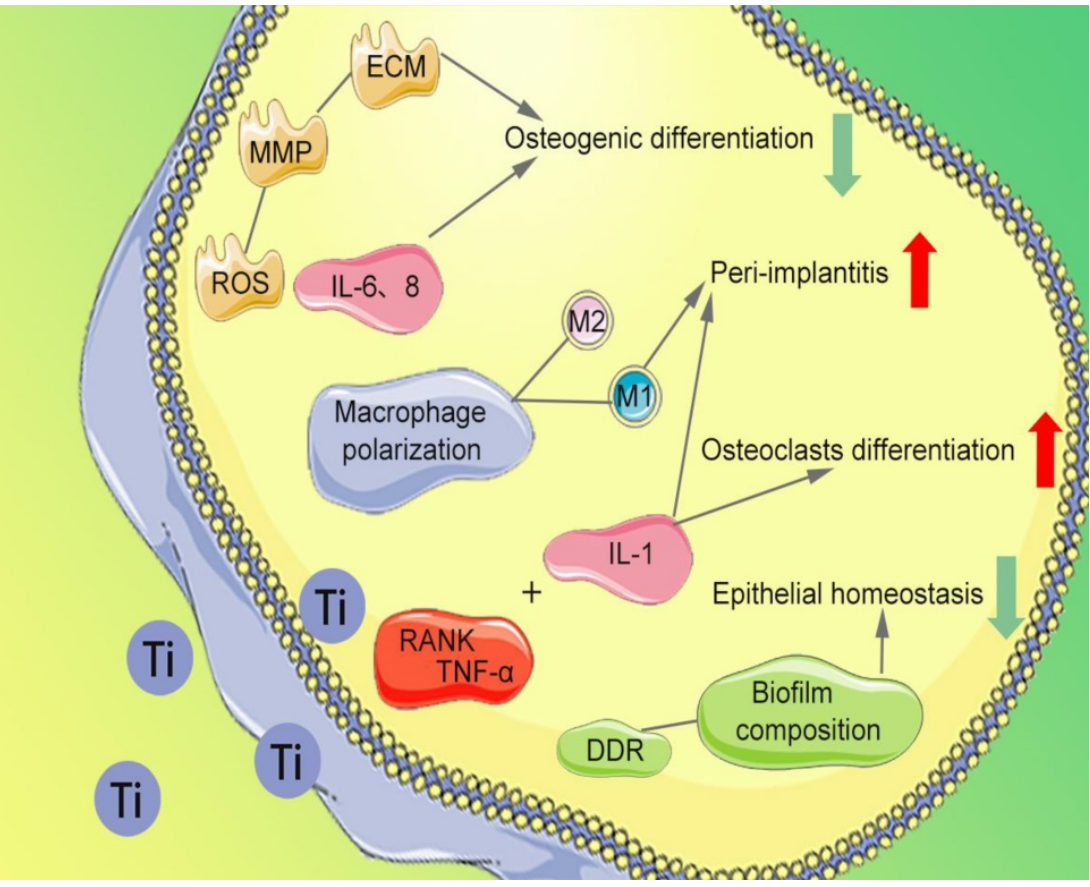

Figure 3. Damage mechanism of Ti particles

Eger et al. studied the relationship between ultrasonic cleaning and release of Ti particles [3]. They found that ultrasonic cleaning of titanium implants causes the release and might also exacerbate peri-implant inflammation. The surface roughness of the implant is changed, influencing formation of biofilm, as well as cells reattachment, which changes the integration process of implant and bone [60]. Non-metallic instruments cause minimal changes and damage to the titanium surface, but they are still related to the release of Ti particles [59]. Hallmon et al. and Homiak et al. found that it also changes the surface after using the plastic curette many times [61, 62].

\section{Damage mechanism on cells}

\subsection{Inhibition of cell activity}

The migration, proliferation, and osteogenesis differentiation of bone marrow mesenchymal stem cells (BMSCs) and osteoblasts on the implant surface are the importance guarantee for implant osseointegration [65]. Several studies have reported that $\mathrm{Ti}$ particles affect the normal cytoskeleton of BMSCs, provoking high levels of reactive oxygen species (ROS) expression, abnormal recruitment of neutrophils [66,67], and production of high levels of matrix metallopeptidase (MMP). The degradation of extracellular matrix (ECM) and inhibition of osteogenesis differentiation of BMSCs are observed. The release of $\mathrm{Ti}$ particles promotes increased concentrations of interleukin (IL)- 6 and IL-8, thereby inhibiting osteoblast function [68], disrupting the bone balance [47], and subsequently leading to bone resorption (Figure 3). After being co-cultured with BMSCs and human osteoblasts respectively [69], the survival rate and vitality of BMSCs and osteoblasts are decrease. In addition, Happe et al. also found that the activity of osteoblasts is negatively correlated with the concentration of Ti particles [70].

\subsection{Stimulation of osteoclast differentiation}

Severe bone resorption at the implant-bone interface is the most common factor for implant failure. The abnormal aggregation of osteoclast precursor cells is considered to be an essential cause of bone resorption. Ti particles have been proved to inhibit the differentiation of osteoblast precursor cells and promote the bone resorption function of osteoclasts by inducing the differentiation of osteoclasts [71]. Wang et al. found that nano-sized $\mathrm{Ti}$ particles can inhibit periodontal ligament cells and the osteogenic differentiation of alveolar bone cells [72]. It promotes secretion of tumor necrosis factor-alpha (TNF-a), IL-1, and receptor activator of nuclear factor- $\mathrm{KB}$ ligand (RANKL), which ultimately promotes differentiation of monocytes into osteoclasts (Figure 3). Furthermore, Ihn et al. found that $\mathrm{Ti}$ particles are taken up by osteoclasts with little effect on the activity of osteoclasts [73]. However, the bone resorption area of titanium-containing medium group' is significantly more extensive than that of the medium without $\mathrm{Ti}$ particles [74]. The number of osteoclasts increased with $\mathrm{Ti}$ particles concentration between $1 \times 10^{4}$ and $4.2 \times 10^{4}$ particles $/ \mathrm{cm}^{2}$ [73]. 


\subsection{Stimulation of macrophages}

Ti particles promote the release of inflammatory factors in the tissues around the implant, leading to infiltration of inflammatory cells and triggering a series of immune-inflammatory responses $[10,19,75]$. Neutrophils and macrophages take up Ti particles of about $2 \mu \mathrm{m}$, resulting in recruitment of inflammatory cells to surrounding tissues [76]. Pajarinen et al. found that the induced degree of inflammation in surrounding tissues depends on polarization of macrophages [75]. Ti particles greatly enhance the overall chemotaxis and inflammatory response of classically activated macrophages (M1) that promote inflammation, while alternatively activated macrophages (M2) that promote regenerative repair are inhibited (Figure 3). Tsutsui et al. found that $\mathrm{Ti}$ particles activate macrophages, promote the release of TNF- $\alpha$ and RANKL receptor activators [77], thereby reducing the formation of osteoprotective proteins. Thus, a microenvironment favorable for osteoclast formation and osteolysis is formed, which lead to bone resorption and implant loosening [78].

\section{Damage mechanism on tissues}

\subsection{Boost peri-implantitis}

Peri-implantitis is one of the primary reasons for implant failure and a common complication of dental implant treatment. It can affect the tissues around the dental implants and cause lose bone. Some reports have reported that $\mathrm{Ti}$ particles are related to peri-implantitis and can promote inflammation reaction $[79,80]$. The content of $\mathrm{Ti}$ particles in the tissues around the implants is also higher than in other areas [81]. Lappas found that metal nanoparticles can induce the abnormal activation of macrophages by regulating host immunity [82], thereby aggravating DNA damage and oxidative stress. Interestingly, some studies have found that metal complex [83], nanoparticles [84] (self-assembly of molecules into nanoparticles, including platinum, aurum, manganese and cerium), and nanoparticles loading drug [23, 24], promote drug internalization, as well as tumor cell necrosis and apoptosis. However, at present, only the negative effect of nanoparticles released from implants has been studied. Ti particles with pro-inflammatory and cytotoxic effects exacerbate the inflammatory response of the tissue surrounding the implant [85, 86], induce peri-implantitis, and destroy the bone homeostasis around the implant, leading to increased bone resorption [3].

\subsection{Damage to oral epithelial homeostasis}

Souza et al. found that $\mathrm{Ti}$ particles affect the composition of biofilms (Figure 3) and change the design of microbes, increasing bacteria types [87], including Streptococcus anginosus, Prevotella nigrescens, Capnocytophaga sputigena, Actinomyces israelli. Suárez-López et al. found that during implantation, Ti particles released from the surface of the implant and activated the DNA damage response of oral epithelial cells via the DNA damage response (DDR) pathway [88], thereby breaking the barrier of oral epithelial and accumulating bacteria around the implant [89]. Bacteria trigger an inflammatory response that further accelerates implant corrosion and the release of $\mathrm{Ti}$ particles. The synergistic effect between mechanical force and bacterial biofilm attenuates the titanium oxide layer and damages the surface of implant, thus intensifying the release [90].

\section{Reduction in the release}

\subsection{Surface modification}

Implant surface modification forming a surface that provides rapid bone healing and immediate implant loading is also a research hotspot in implant surface processing techniques that are related to release rate of $\mathrm{Ti}$ particles. To promote the osseointegration of the implant and the surrounding bone, the modification methods usually are categorized into surface addition, surface reduction, surface bombardment, and surface oxidation [91].

Deppe et al. found that the surface treated by surface reduction method has less wear than that of the surface addition one [92]. Titanium implants with different surfaces are implanted into the femur and tibia of sheep, including smooth titanium (STi), titanium plasma-sprayed (TPS), alumina oxide sandblasted and acid-etched (Al-SLA), zirconium oxide sandblasted, and acid-etched (Zr-SLA). Franchi et al. found that $\mathrm{Ti}$ particles detached from the implant surface are visible at the TPS implant-bone interface at 0 and 14 days after implantation [93]. Similarly, Weingart et al. also detected Ti particles on the surface of TPS implants implanted in beagles nine months postoperatively [6]. Schliephake et al. observed the shedding of Ti particles after implanting STi implants [94], but the release of Ti particles is less than TPS implant. Less Ti particles are released by surface reduction method because the released $\mathrm{Ti}$ particles are looser and the damaged titanium oxide layer is easier to reconstruct.

Several reports indicate that the "plus" Ti surface used for deposition of particles (such as TPS) is more abrasion than the "minus" Ti surface (such as STi), 
which make it easier to release the Ti particles from the implant.

\subsection{Selection of materials}

Titanium implants are mainly used in dental implants, but the superstructure such as abutment has multiple options, including vanadium, aluminum, cobalt, chromium, molybdenum, zirconia. It is reported that materials with different mechanical properties have close contact and interaction with each other, while those with weaker mechanical properties have more wear and deformation. Zirconia is a commonly used material for the superstructure of implants, and its flexural strength is greater than that of titanium [95, 96]. Klotz et al. applied a force of $20 \mathrm{~N}$ to $200 \mathrm{~N}$ on the titanium and zirconia abutments of titanium implants [97], and found that titanium implants with zirconia abutments appear to a greater extent than titanium implants with titanium abutments. Thus, the latter is less resistant to wear and releases more Ti particles. Tawse-Smith A et al. also found that the loading of the zirconia canopy of a single implant can cause wear on the titanium surface and lead to the Ti particles release [98]. Similarly, the interaction between pure titanium and titanium alloys with higher hardness also emerged more deformation and wear of pure titanium implants.

Platform switching is defined as a protocol that includes small-diameter restoration components that have been placed on large-diameter implant restoration platforms. The outer edge of the implant abutment interface is away from the outer edge of the implant platform. Alrabeah et al. combined titanium implants with pure titanium, gold alloy, cobaltchrome alloy, and zirconia abutments, respectively. It is divided into platform matching and platform switching groups $[99,100]$. It is found that the release of metal in all platform switching groups is lower than that of the platform matching group. The release of titanium is found in all experimental groups, and the wear particles are mainly Ti particles. The average amount of Ti particles is the highest in the implant with the platform matching the gold abutment.

It suggested that materials with similar hardness and mechanical properties should be used as much as possible to reduce the wear on the base when selecting implant materials. Platform-switching has a positive effect in reducing the levels of metal release from the implant-abutment.

\subsection{Clinical Treatment}

Grenón et al. found that the diffusion coefficient of $\mathrm{Ti}$ particles changes over time. The one-month diffusion coefficient is more significant than three months postoperatively and released more $\mathrm{Ti}$ particles [101]. Metal particles and ions are diluted and removed by rinsing the surgical site, reducing the total amount of metal [102]. Early release of $\mathrm{Ti}$ particles can be effectively reduced by checking the integrity of the cutting tool before use, fully controlling the number of disinfection procedures, and replacing the worn drill bit. Surgery contamination such as suction and swallowing, is also responsible for the distribution of Ti particles in distal organs [11].

Clinicians should pay attention to the effect of instruments used and chemicals on the implant surface to reduce the release of $\mathrm{Ti}$ particles during the maintenance. Cha et al. compared the effects of five kinds of mechanical equipment (metal clean tooth tip, thermoplastic clean tooth tip, round brush titanium, titanium bristle brush, and glycine abrasive) on the surface roughness of implants [103]. They found that the metal teeth cleaning device has apparent damage to the implant surface. Glycine abrasive seems to grow on the surface of the body surface damage to the minimum, thus releasing the least Ti particles.

Therefore, it suggested that the device with little influence on the surface roughness of implant should be chosen when maintaining the implant.

\section{Reduction in toxicity}

Ti particles can inhibit a variety of cell activities, and promote osteoclast differentiation. Biochemical and immunohistochemical analysis indicates that IL-6, IL-1, and TNF-a and other cytokines are highly expressed in peri-implant tissues and can stimulate bone resorption. Therefore, it is critical to reduce or inhibit the toxicity of Ti particles. Several studies have reported that the release is relate to some open pathways and various active substances, effectively reducing the toxicity (Table 3 ).

\subsection{Inhibition of effect of inflammatory cytokines}

The release of $\mathrm{Ti}$ particles can induce an inflammatory response and promote bone tissue absorption around the implant. Eger et al. found that systematically or locally blocking the release of IL-1 $\beta$, IL-6, and TNF- $\alpha$ around titanium implants can reduce bone resorption induced by the Ti particles [104]. Through the phosphatidylinositol 3-kinase-AKT (Pl3K-AKT) signaling pathway, the production of TNF-a is reduced, which could minimize osteolysis and implant loosening [105]. Bacterial endotoxin can also enhance the adverse effects of Ti particles, which reduces the production of TNF-a by PI3K inhibitors on the particles with adherent endotoxin by $70 \%$ without increasing cytotoxicity. Similarly, the AKT 
inhibitor can reduce TNF-a production by $83 \%$ without increasing cytotoxicity.

\subsection{Ceramic coating of bioactive substances}

Bioactive substances ceramic coatings on titanium substrates can effectively promote osseointegration and reduce the pro-inflammatory effect of Ti particles on surrounding tissues [106].

Rutile particles are mainly used as enhancers in the manufacture of composite materials [107]. Several surface modifications that give rise to an outer ceramic layer of rutile have been developed to improve implant wear and corrosion resistance. The rutile layer enhances the adhesion of osteoblast in vitro and improves bone fixation in vivo [108-110]. Vallés et al. cultured the mononuclear macrophages with Ti particles, and found that the amount of TNF-a and IL-6 released by the cells is higher than that of rutile, and the level of cytokine secretion is lower than Ti particles after cultured with rutile particles [111]. Higher biocompatibility of titanium-based implants modified with an outer surface layer of rutile is expected to reduce the toxicity of Ti particles.

$\mathrm{Li}$ et al. found that magnesium $(\mathrm{Mg})$ is an anti-inflammatory agent that inhibits inflammation and promotes osteogenesis, so that bone biomaterials have anti-inflammatory effects [112]. It inhibits the expression of macrophage M1 markers and pro-inflammatory cytokines, reduces the release of TNF-a after co-cultivation with magnesium ions. Moreover, macrophages grown on Mg-containing ceramic coating surfaces are switched from M1 to M2 phenotype with the stimulation of lipopolysaccharide (LPS), which has the same effect. The integration of $\mathrm{Mg}$ in biomaterials can reduce the pro-inflammatory effect of $\mathrm{Ti}$ particles on the tissue surrounding the implant.

\subsection{Using plant extracts}

Some plants inhibit titanium particles toxicity by preventing the release of inflammatory cytokines. Quercetin (QUE) is commonly found in plants and exerted anti-inflammatory effects [113, 114]. The cytotoxicity of $\mathrm{Ti}$ particles is inhibited after pretreatment with QUE. Zhang et al. found that QUE reduced the release of inflammatory cytokines from mononuclear macrophages caused by $\mathrm{Ti}$ particles [115]. In addition, treatment with QUE can significantly reduce the number of osteoclasts. In the mouse skull osteolysis model, QUE inhibits osteolysis caused by $\mathrm{Ti}$ particles in vivo by inhibiting the formation of osteoclast.

Table 3. Correlative study of different active substances on the inflammatory response and bone resorption induced by $\mathrm{Ti}$ particles

\begin{tabular}{|c|c|c|c|c|}
\hline $\begin{array}{l}\text { Author } \\
\text { (Year) }\end{array}$ & Active substance & Titanium particles size & Inhibit the effects of $\mathrm{Ti}$ particles & Mechanism \\
\hline $\begin{array}{l}\text { Zichuan } \\
\text { Ping et al. } \\
(2017)\end{array}$ & Melatonin & $3.32 \pm 2.39 \mu \mathrm{m}$ & $\begin{array}{l}\text { Inhibition of bone resorption and } \\
\text { expression of inflammatory cytokines }\end{array}$ & $\begin{array}{l}\text { Suppression of NF-kB } \\
\text { signaling }\end{array}$ \\
\hline $\begin{array}{l}\text { Ziguan } \\
\text { Zhu et al. } \\
(2018)\end{array}$ & Aucubin & $3-4 \mu \mathrm{m}$ & $\begin{array}{l}\text { Inhibit the apoptosis of Mc3t3-e1 cells and } \\
\text { promote osteogenesis }\end{array}$ & $\begin{array}{l}\text { Affecting the } \\
\text { BMP2/Smads/RunX2 } \\
\text { signaling pathway }\end{array}$ \\
\hline $\begin{array}{l}\text { Chenhao } \\
\text { Pan et al. } \\
(2019)\end{array}$ & 20(S)-protopanaxadiol (PDD) & $1-3 \mu \mathrm{m}$ & $\begin{array}{l}\text { Inhibition of osteoclast formation and } \\
\text { release of inflammatory cytokines }\end{array}$ & $\begin{array}{l}\text { Inhibition of MAPK and NF- } \\
\text { B signaling pathways }\end{array}$ \\
\hline $\begin{array}{l}\text { Ruize Qu } \\
\text { et al. (2019) }\end{array}$ & Ghrelin & $3.32 \pm 2.39 \mathrm{~mm}$ & $\begin{array}{l}\text { Inhibit the inflammatory response; } \\
\text { Reduce osteoblasts formation injury and } \\
\text { bone resorption }\end{array}$ & $\begin{array}{l}\text { Activation of } \beta \text {-Catenin } \\
\text { Signaling Pathway }\end{array}$ \\
\hline $\begin{array}{l}\text { Chao Yang } \\
\text { et al. (2019) }\end{array}$ & Curcumin & & $\begin{array}{l}\text { Inhibition of osteoclast maturation and } \\
\text { formation stimulated by RANKL has an } \\
\text { immunomodulatory effect on macrophage } \\
\text { polarization }\end{array}$ & $\begin{array}{l}\text { Activates the Akt/NF B/ } \\
\text { NFATc1 pathway }\end{array}$ \\
\hline $\begin{array}{l}\text { Chao Yang } \\
\text { et al. (2019) }\end{array}$ & Puerarin & & $\begin{array}{l}\text { Inhibition of bone resorption and } \\
\text { production of pro-inflammatory } \\
\text { cytokines; Inhibition of osteoclast } \\
\text { activation. }\end{array}$ & $\begin{array}{l}\text { Reduced } \\
\text { RANKL-stimulated } \\
\text { MEK/ERK/NFATc1 } \\
\text { signaling cascades }\end{array}$ \\
\hline $\begin{array}{l}\text { Chao Yang } \\
\text { et al. (2019) }\end{array}$ & Lithium chloride & & $\begin{array}{l}\text { Increases the release of anti-inflammatory } \\
\text { and osteocellular factors. }\end{array}$ & $\begin{array}{l}\text { Induction of macrophage } \\
\text { polarization, M2 phenotype }\end{array}$ \\
\hline $\begin{array}{l}\text { Chao Yang } \\
\text { et al. (2020) }\end{array}$ & Naringin & $1-3 \mu \mathrm{m}$ & $\begin{array}{l}\text { Inhibits the release of inflammatory } \\
\text { factors TNF- and IL-6 }\end{array}$ & Inhibit P38 MAPK pathway \\
\hline $\begin{array}{l}\text { Xiang Wei } \\
\text { et al. (2020) }\end{array}$ & $\begin{array}{l}\text { DAPT(N-[N-(3,5-difluorohenacetyl)-l-alanyl]- } \\
\text { S-phenylglycine tert-butyl ester, GSI-IX) }\end{array}$ & & $\begin{array}{l}\text { Inhibition of osteoclast formation and } \\
\text { function; Almost no osteoclasts were } \\
\text { formed under high concentration DAPT. }\end{array}$ & $\begin{array}{l}\text { Suppressing the } \\
\text { RANKL/Notch2 signaling } \\
\text { pathway DAPT }\end{array}$ \\
\hline $\begin{array}{l}\text { Zhenyu } \\
\text { Sun et al. } \\
(2020)\end{array}$ & Magnoflorine & & $\begin{array}{l}\text { Inflammatory bone resorption was } \\
\text { inhibited in vivo and osteoclast formation } \\
\text { was inhibited in vitro }\end{array}$ & $\begin{array}{l}\text { Suppression of MAPK and } \\
\text { NF-kB Signaling }\end{array}$ \\
\hline $\begin{array}{l}\text { Zhiwei } \\
\text { Zhang et } \\
\text { al. (2020) }\end{array}$ & $\begin{array}{l}\text { Bortezomib (BTZ), } \\
\text { Nanosized and Alumina }(\mathrm{Al}) \text { particles }\end{array}$ & $<5 \mu \mathrm{m}$ & $\begin{array}{l}\text { Reduces apoptosis, inflammation and } \\
\text { bone resorption }\end{array}$ & $\begin{array}{l}\text { Reduced NF- B activation of } \\
\text {-TRCP and decreased } \\
\text { expression of Caspase- } 3\end{array}$ \\
\hline
\end{tabular}


Luteolin is a highly effective TNF-a, IL-6, and nitric oxide inhibitor. In mouse models of acute and chronic inflammation, oral luteolin inhibits the inflammatory response [116]. Shin et al. found that luteolin inhibits osteoclast production and bone resorption caused by macrophages by inhibiting the release of inflammatory cytokines induced by $\mathrm{Ti}$ particles [117].

Astragaloside IV (As-IV) is a natural plant extract that increases the activity of osteoblasts and has the potential to treat osteoclast-related diseases, including osteoporosis, periodontal disease, and rheumatoid joints inflammation and loosening of the sterile prosthesis. Li et al. found that intravenous injection of As-IV reduces the osteolysis of mice induced by Ti particles [118].

Above all, it is not difficult to find that controlling or inhibiting the release of inflammatory factors and bone resorption are the main approach to reduce the toxicity of $\mathrm{Ti}$ particles. The basic mechanism is to limit inflammation, either by coating of bioactive substances or by using plant extracts. This is closely related to peri-implantitis, which is one of the main causes of implant failure. Therefore, it is necessary for us to pay attention to and study how to reduce the toxicity of Ti particles.

\section{Conclusion and perspectives}

Titanium metal is considered the safest material for implants due to its excellent mechanical properties and biocompatibility. It has been widely used in oral, orthopedics, and plastic surgery. The titanium oxide layer on the implant surface can be damaged by mechanical wear and chemical corrosion in long-term use and daily care, causing the release. It varies in size, shape, and content in local and remote, destroy the bone homeostasis around the implant and further aggravate the inflammatory response of surrounding tissues, which triggers peri-implantitis. The potential impact on other cells, tissues, and organs still needs to be explored. This paper has emphasized the methods of reducing the release and toxicity of $\mathrm{Ti}$ particles. However, it is still impossible to eliminate Ti particles and achieve zero release. Currently, 1000 tons of titanium is implanted into patients in various forms every year, but the release of $\mathrm{Ti}$ particles has not attracted the attention of clinicians. With the advent of new materials and advances in technology, such as atomic layer deposition technology and so on, it is believed that more methods to prevent and reduce the release of Ti particles will soon be applied to basic and clinical research.

In recent years, the rapid development of nanomedicine has promoted the cross integration of many fields. Various metal nanoparticles including precious metal nanoparticles, transition metal nanoparticles, have been successively used in the field of biomedicine to effectively treat some major diseases, such as cancer and Alzheimer's disease. Regarding the Ti particles and titanium nanoparticles released by dental implants, most of the research has focused on how to inhibit their inflammatory response and bone resorption, and their comparison with different metal particles is rare. Consider whether the Ti particles released on implants can be converted to beneficial effects by adding drugs or in some way, similar to implants carrying natural nanoparticles, which are released into the surrounding tissues and have an impact.

\section{Abbreviations}

Ti particles: titanium particles; SLA: sandblasting acid etching; LA-ICP-MS: laser ablation inductively coupled plasma mass spectroscopy; BMSC: bone marrow mesenchymal stem cells; ROS: reactive oxygen species; MMP: matrix metallopeptidase; ECM: extracellular matrix; IL: interleukin; TNF-a: tumor necrosis factor-alpha; RANKL: receptor activator of nuclear factor- $\mathrm{kB}$ ligand; M: macrophages; DDR: DNA damage response; STi: smooth titanium; TPS: titanium plasma-sprayed; Al-SLA: alumina oxide sandblasted and acid-etched; Zr-SLA: zirconium oxide sandblasted, and acid-etched; Pl3K-AKT: phosphatidylinositol 3-kinase-AKT; Mg: magnesium; LPS: lipopolysaccharide; QUE: quercetin; As-IV: astragaloside IV; mBMMs: mouse bone marrow macrophages; TRG: trigeminal root ganglion; SEM: scanning electron microscopy; BSE: back-scattered electron; EDS: energy dispersive X-ray; FAAS: flameless atomic absorption spectroscopy; LM: light microscopy; TEM: transmission electron microscopy; ICP-AES: coupled plasma atomic emission spectroscopy.

\section{Acknowledgments}

This work was supported by Shanxi Province Key Research and Development Program (201903D321148), National Natural Science Foundation of China (81801004 and 82071155 and 81901034), Scientific and Technological Innovation Programs of Higher Education Institutions in Shanxi (2019L0438 and 2020L0209).

\section{Competing Interests}

The authors have declared that no competing interest exists. 


\section{References}

1. Zhou YM. Prosthodontics. Beijing: People's Medical Publishing House. 2012;371.

2. Suárez-López Del Amo F, Garaicoa-Pazmiño C, Fretwurst T, Castilho RM, Squarize $\mathrm{CH}$. Dental implants-associated release of Ti particles: A systematic review. Clin Oral Implants Res. 2018; 29(11):1085-1100.

3. Eger M, Sterer N, Liron T, Kohavi D, Gabet $\mathrm{Y}$. Scaling of titanium implants entrains inflammation-induced osteolysis. Sci Rep. 2017; 7: 39612.

4. $\mathrm{Xu} \mathrm{J}$, Aoki $\mathrm{H}$, Kasugai S, Otsuka M. Enhancement of mineralization on porous titanium surface by filling with nano-hydroxyapatite particles fabricated with a vacuum spray method. Mater Sci Eng C Mater Biol Appl. 2020; 111: 110772.

5. Berryman Z, Bridger L, Hussaini HM, Rich AM, Atieh M, Tawse-Smith A. Titanium particles: An emerging risk factor for peri-implant bone loss. Saudi Dent J. 2020; 32(6):283-292.

6. Heringa MB, Peters RJB, Bleys RLAW, van der Lee MK, Tromp PC, van Kesteren PCE, et al. Detection of titanium particles in human liver and spleen and possible health implications. Part Fibre Toxicol. 2018; 15(1):15.

7. He X, Reichl FX, Wang Y, et al. Analysis of titanium and other metals in human jawbones with dental implants - A case series study. Dent Mater. 2016; 32(8):1042-1051

8. Yang JW, Zhang HD, et al. European Association for Osseointegration. [Key points for clinical practice from the EAO 2018 consensus conference]. Zhonghua Kou Qiang Yi Xue Za Zhi. 2019; 54(5):297-302. Chinese.

9. Yu B, Bai J, Shi J, Shen J, Guo X, Liu Y, et al. MiR-106b inhibition suppresses inflammatory bone destruction of wear debris-induced periprosthetic osteolysis in rats. J Cell Mol Med. 2020; 24(13):7490-7503.

10. Obando-Pereda GA, Fischer L, Stach-Machado DR. Titanium and zirconia particle-induced pro-inflammatory gene expression in cultured macrophages and osteolysis, inflammatory hyperalgesia and edema in vivo. Life Sci. 2014; 97: 96-106.

11. Berger CA, Arkhipova M, Farkas A, Maas G, Jacob T. Titanium deposition from ionic liquids - appropriate choice of electrolyte and precursor. Phys Chem Chem Phys. 2016; 18(6):4961-5.

12. Pettersson M, Pettersson J, Molin Thorén M, Johansson A. Release of titanium after insertion of dental implants with different surface characteristics-an $e x$ vivo animal study. Acta Biomater Odontol Scand. 2017; 3(1):63-73.

13. Wennerberg A, Jimbo R, Allard S, Skarnemark G, Andersson M. In vivo stability of hydroxyapatite nanoparticles coated on titanium implant surfaces. Int J Oral Maxillofac Implants. 2011; 26(6):1161-1166.

14. Mathew MT, Abbey S, Hallab NJ, Hall DJ, Sukotjo C, Wimmer MA. Influence of $\mathrm{pH}$ on the tribocorrosion behavior of $\mathrm{CpTi}$ in the oral environment: synergistic interactions of wear and corrosion. J Biomed Mater Res B Appl Biomater. 2012; 100(6):1662-71.

15. Moran MM, Wilson BM, Ross RD, Virdi AS, Sumner DR. Arthrotomy-based preclinical models of particle-induced osteolysis: A systematic review. J Orthop Res. 2017; 35(12):2595-2605.

16. Zhang L, Haddouti EM, Welle K, Burger C, Wirtz DC, Schildberg FA, et al. The Effects of Biomaterial Implant Wear Debris on Osteoblasts. Front Cell Dev Biol. 2020; 8:352

17. Frisken KW, Dandie GW, Lugowski S, Jordan G. A study of titanium release into body organs following the insertion of single threaded screw implants into the mandibles of sheep. Aust Dent J. 2002;47(3):214-7.

18. Bitar D, Parvizi J. Biological response to prosthetic debris. World J Orthop. 2015; 6(2):172-189

19. Grosse S, Haugland HK, Lilleng P, Ellison P, Hallan G, Høl PJ. Wear particles and ions from cemented and uncemented titanium-based hip prostheses-a histological and chemical analysis of retrieval material. J Biomed Mater Res B Appl Biomater. 2015; 103(3):709-717.

20. Curtin JP, Wang M. Are clinical findings of systemic titanium dispersion following implantation explained by available in vitro evidence? An evidence-based analysis. J Biol Inorg Chem. 2017; 22(6):799-806.

21. Wang Q, Zhou P, Liu S, Attarilar S, Ma RL, Zhong Y, Wang L. Multi-Scale Surface Treatments of Titanium Implants for Rapid Osseointegration: A Review. Nanomaterials (Basel). 2020 Jun 26; 10(6):1244

22. Verma R, Singh A, Badni M, Chandra A, Gupta S, Verma R. Evaluation of exfoliative cytology in the diagnosis of oral premalignant and malignant lesions: A cytomorphometric analysis. Dent Res J (Isfahan). 2015; 12(1):83-8.

23. Yang $Y, Y u$ Y, Chen H, Meng X, Ma W, Yu M, et al. Illuminating Platinum Transportation while Maximizing Therapeutic Efficacy by Gold Nanoclusters via Simultaneous Near-Infrared-I/II Imaging and Glutathione Scavenging. ACS Nano. 2020; 14(10):13536-13547.

24. Yang $\mathrm{Y}, \mathrm{Liu} \mathrm{X}, \mathrm{Ma} \mathrm{W}, \mathrm{Xu} \mathrm{Q}$, Chen $\mathrm{G}$, Wang $\mathrm{Y}$, et al. Light-activatable liposomes for repetitive on-demand drug release and immunopotentiation in hypoxic tumor therapy. Biomaterials. 2021; 265:120456.

25. Olmedo DG, Nalli G, Verdú S, Paparella ML, Cabrini RL. Exfoliative cytology and titanium dental implants: a pilot study. J Periodontol. 2013; 84(1):78-83.

26. Sajnóg A, Hanć A, Koczorowski R, Barałkiewicz D. New procedure of quantitative mapping of $\mathrm{Ti}$ and $\mathrm{Al}$ released from dental implant and $\mathrm{Mg}, \mathrm{Ca}$, $\mathrm{Fe}, \mathrm{Zn}, \mathrm{Cu}, \mathrm{Mn}$ as physiological elements in oral mucosa by LA-ICP-MS. Talanta. 2017; 175:370-381.

27. Swiatkowska I, Martin N, Hart AJ. Blood titanium level as a biomarker of orthopaedic implant wear. J Trace Elem Med Biol. 2019; 53:120-128.
28. Delgado-Ruiz R, Romanos G. Potential Causes of Titanium Particle and Ion Release in Implant Dentistry: A Systematic Review. Int J Mol Sci. 2018; 19(11):3585.

29. Siniscalchi EN, Catalfamo L, Allegra A, Musolino C, De Ponte FS. Titanium miniplates: a new risk factor for the development of the bisphosphonate-related osteonecrosis of the jaw. J Craniofac Surg. 2013; 24(1): e1-2.

30. Nautiyal VP, Mittal A, Agarwal A, Pandey A. Tissue response to titanium implant using scanning electron microscope. Natl J Maxillofac Surg. 2013; 4(1):7-12.

31. Penmetsa SLD, Shah R, Thomas R, Kumar ABT, Gayatri PSD, Mehta DS. Titanium particles in tissues from peri-implant mucositis: An exfoliative cytology-based pilot study. J Indian Soc Periodontol. 2017; 21(3):192-194.

32. Williams DF, Williams RL. Degradative effects of the biological environment on metals and ceramics. Biomaterials Science. An Introduction to Materials in Medicine, 2013; 2:430-439.

33. Sarmiento-González A, Encinar JR, Marchante-Gayón JM, Sanz-Medel A. Titanium levels in the organs and blood of rats with a titanium implant, in the absence of wear, as determined by double-focusing ICP-MS. Anal Bioanal Chem. 2009; 393(1):335-343

34. Hanawa T. Metal ion release from metal implants. Materials Science \& Engineering C. 2004; 24(6-8):745-752

35. Rodrigues DC, Valderrama P, Wilson TG, et al. Titanium Corrosion Mechanisms in the Oral Environment: A Retrieval Study. Materials (Basel). 2013; 6(11):5258-5274.

36. Hjalmarsson L, Smedberg JI, Wennerberg A. Material degradation in implant-retained cobalt-chrome and titanium frameworks. J Oral Rehabil. 2011; 38(1):61-71

37. Henry PJ. Clinical experiences with dental implants. Advances in Dental Research. 1999; 13

38. Berbel LO, Banczek EDP, Karoussis IK, Kotsakis GA, Costa I. Determinants of corrosion resistance of Ti-6Al-4V alloy dental implants in an In Vitro model of peri-implant inflammation. PLoS One. 2019 Jan 31; 14(1): e0210530.

39. Noguti J, de Oliveira F, Peres RC, Renno AC, Ribeiro DA. The role of fluoride on the process of titanium corrosion in oral cavity. Biometals. 2012; 25(5):859-62

40. Licausi MP, Igual Muñoz A, Amigó Borrás V. Influence of the fabrication process and fluoride content on the tribocorrosion behaviour of Ti6Al4V biomedical alloy in artificial saliva. J Mech Behav Biomed Mater. 2013; 20:137-148.

41. Mohiti A, Eslami F, Dehestani MR. Does Hypertension affect Saliva Properties? J Dent (Shiraz). 2020; 21(3):190-194.

42. Cruz HMV, Souza JCM, Henriques M, Rocha LA. Tribocorrosion and bio-tribocorrosion in the oral environment: The case of dental implants. Biomedical Tribology. 2011; p:1-33.

43. Souza JCM, Henriques M, Teughels W, Ponthiaux P, Celis JP, Rocha LA. Wear and corrosion interactions on titanium in oral environment: Literature review. J. Bio-Tribo-Corros. 2015; 1: 13.

44. Gil FJ, Canedo R, Padros A, Baneres MV, Arano JM. Fretting corrosion behaviour of ball-and-socket joint on dental implants with different prosthodontic alloys. Biomed. Mater. Eng. 2003; 13: 27-34.

45. Gittens RA, Olivares-Navarrete R, Tannenbaum R, Boyan BD, Schwartz Z Electrical implications of corrosion for osseointegration of titanium implants. J Dent Res. 2011; 90(12):1389-1397.

46. Wheelis SE, Gindri IM, Valderrama P, Wilson TG, Huang I, Rodrigues DC Effects of decontamination solutions on the surface of titanium: Investigation of surface morphology, composition, and roughness. Clin. Oral Implant. Res. 2016; 27: 329-340.

47. Chen WO Zhang SM, Oiu J. Surface analysis and corrosion behavior of pure titanium under fluoride exposure. J Prosthet Dent. 2020; 124(2): 239.e1-239.e8.

48. Mouhyi J, Dohan Ehrenfest DM, Albrektsson T. The peri-implantitis: implant surfaces, microstructure, and physicochemical aspects. Clin Implant Dent Relat Res. 2012; 14(2):170-183.

49. Prando D, Brenna A, Diamanti MV, Beretta S, Bolzoni F, Ormellese M, et al. Corrosion of titanium: Part 1: aggressive environments and main forms of degradation. J Appl Biomater Funct Mater. 2017; 15(4): e291-e302.

50. Barrak FN, Li S, Muntane AM, Jones JR. Particle release from implantoplasty of dental implants and impact on cells. Int J Implant Dent. 2020 Sep 12;6(1):50.

51. Suvarna GS, Nadiger RK, Shetty O. Effect of Topical Fluoride on Surface of Cast Titanium and Nickel-Chromium: An In Vitro Study. J Dent (Tehran). $2015 ; 12(6): 398-408$

52. Muguruma T, Iijima M, Brantley WA, Yuasa T, Kyung HM, Mizoguchi I. Effects of sodium fluoride mouth rinses on the torsional properties of miniscrew implants. Am J Orthod Dentofacial Orthop. 2011; 139(5):588-593.

53. Toniollo MB, Galo R, Macedo AP, Rodrigues RC, Ribeiro RF, Mattos Mda G. Effect of fluoride sodium mouthwash solutions on cpTI: evaluation of physicochemical properties. Braz Dent J. 2012; 23(5):496-501.

54. Schiff N, Grosgogeat B, Lissac M, Dalard F. Influence of fluoride content and $\mathrm{pH}$ on the corrosion resistance of titanium and its alloys. Biomaterials. 2002; 23(9):1995-2002

55. Hong Guan, Rudi C. van Staden, Newell W. Johnson, Yew-Chaye Loo. Dynamic modelling and simulation of dental implant insertion process-A finite element study. Finite Elements in Analysis \&amp; Design. 2011; 47(8). 
56. Wennerberg A, Albrektsson T. Effects of titanium surface topography on bone integration: a systematic review. Clin Oral Implants Res. 2009; 20(Suppl 4):172-84.

57. Schou S, Berglundh T, Lang NP. Surgical treatment of peri-implantitis. Int. J. Oral Maxillofac. Implant. 2004; 19: 140-149.

58. Sirinirund B, Garaicoa-Pazmino C, Wang HL. Effects of Mechanical Instrumentation with Commercially Available Instruments Used in Supportive Peri-implant Therapy: An In Vitro Study. Int J Oral Maxillofac Implants. 2019; 34(6):1370-1378

59. Louropoulou A, Slot DE, van der Weijden FA. Titanium surface alterations following the use of different mechanical instruments: A systematic review. Clin. Oral Implants Res. 2012; 23: 643-658.

60. Sato S, Kishida M, Ito K. The comparative effect of ultrasonic scalers on titanium surfaces: an in vitro study. J Periodontol. 2004; 75(9):1269-73.

61. Hallmon WW, Waldrop TC, Meffert RM, Wade BW. A comparative study of the effects of metallic, nonmetallic, and sonic instrumentation on titanium abutment surfaces. Int. J. Oral Maxillofac. Implant. 1996; 11: 96-100.

62. Homiak AW, Cook PA, DeBoer J. Effect of hygiene instrumentation on titanium abutments: A scanning electron microscopy study. J. Prosthet. Dent. 1992; 67: 364-369.

63. Augthun $\mathrm{M}$, Tinschert J, Huber A. In vitro studies on the effect of cleaning methods on different implant surfaces. J. Periodontol. 1998; 69: 857-864.

64. Rajeswari CL, Kumar MV. Effect of oral prophylactic instrumentation on the surface texture of all metal restorative materials. J Indian Prosthodont Soc. 2015; 15(1):39-45.

65. Takeda A, Yamazaki Y, Baba K, Ishiguro M, Aoyagi K, Ikemoto S, et al. Osteogenic potential of human bone marrow-derived mesenchymal stromal cells cultured in autologous serum: a preliminary study. J Oral Maxillofac Surg. 2012; 70(8): e469-76.

66. Cheng W, Meng B. The research of Ti particles on the behavior of mouse bone mesenchymal stem cells in vitro. Chinese Journal of Oral Implantology. 2010; 15(02):51-54.

67. Bressan E, Ferroni L, Gardin C, et al. Metal Nanoparticles Released from Dental Implant Surfaces: Potential Contribution to Chronic Inflammation and Peri-Implant Bone Loss. Materials (Basel). 2019; 12(12):2036.

68. Lochner K, Fritsche A, Jonitz A, Hansmann D, Mueller P, Mueller-Hilke B, et al. The potential role of human osteoblasts for periprosthetic osteolysis following exposure to wear particles. Int J Mol Med. 2011 Dec; 28(6):1055-63.

69. Costa BC, Alves AC, Toptan F, Pinto AM, Grenho L, Fernandes MH, et al. Exposure effects of endotoxin-free titanium-based wear particles to human osteoblasts. J Mech Behav Biomed Mater. 2019; 95:143-152.

70. Happe A, Sielker S, Hanisch M, Jung S. The Biological Effect of Particulate Titanium Contaminants of Dental Implants on Human Osteoblasts and Gingival Fibroblasts. Int J Oral Maxillofac Implants. 2019; 34(3).

71. Wang LH, Fan LJ, Gu ZY. Phenomena and mechanism of bone resorption induced by titanium ion. International Journal of Stomatology. 2009; 36(04):441-443+447.

72. Wang BH, Liu CY, Wang XY, Li Y. Effect of Ti particles on the surface of dental implants on periodontal ligament stem cells. Beijing Journal of Stomatology. 2019; 27(03):137-142

73. Ihn HJ, Kim K, Cho HS, Park EK. Pentamidine Inhibits Titanium Particle-Induced Osteolysis In Vivo and Receptor Activator of Nuclear Factor-кB Ligand-Mediated Osteoclast Differentiation In Vitro. Tissue Eng Regen Med. 2019; 16(3):265-273

74. Meng B, Cheng W, Yang XY, Lai CH. The effect of Ti particles on the bone resorption ability of osteoclasts. Chinese Journal of Oral Implantology. 2012; 17(01):6-9.

75. Pajarinen J, Kouri VP, Jämsen E, Li TF, Mandelin J, Konttinen YT. The response of macrophages to titanium particles is determined by macrophage polarization. Acta Biomater. 2013; 9:9229-9240.

76. Placko HE, Mishra S, Weimer JJ, Lucas LC. Surface characterization of titanium-based implant materials. Int J Oral Maxillofac Implants. 2000; 15(3):355-63.

77. Tsutsui T, Kawaguchi H, Fujino A, Sakai A, Kaji H, Nakamura T. Exposure of macrophage-like cells to titanium particles does not affect bone resorption, but inhibits bone formation. J Orthop Sci. 1999; 4(1):32-38.

78. Goodman SB, Gallo J. Periprosthetic Osteolysis: Mechanisms, Prevention and Treatment. J Clin Med. 2019; 8(12):2091.

79. Christiansen RJ, Münch HJ, Bonefeld CM, Thyssen JP, Sloth JJ, Geisler C, et al. Cytokine Profile in Patients with Aseptic Loosening of Total Hip Replacements and Its Relation to Metal Release and Metal Allergy. J Clin Med. 2019; 8(8):1259.

80. Pettersson M, Kelk P, Belibasakis GN, Bylund D, Molin Thorén M, Johansson A. Titanium ions form particles that activate and execute interleukin- $1 \beta$ release from lipopolysaccharide-primed macrophages. J Periodontal Res. 2017; 52(1):21-32.

81. Pettersson M, Pettersson J, Johansson A, Molin Thorén M. Titanium release in peri-implantitis. J Oral Rehabil. 2019; 46(2):179-188.

82. Lappas, C.M. The immunomodulatory effects of titanium dioxide and silver nanoparticles. Food Chem. Toxicol. 2015, 85, 78-83.

83. Chen G, Yang Y, Xu Q, Ling M, Lin H, Ma W, et al. Self-Amplification of Tumor Oxidative Stress with Degradable Metallic Complexes for Synergistic Cascade Tumor Therapy. Nano Lett. 2020; 20(11):8141-8150.
84. Xiao YF, An FF, Chen JX, Yu J, Tao WW, Yu Z, et al. The Nanoassembly of an Intrinsically Cytotoxic Near-Infrared Dye for Multifunctionally Synergistic Theranostics. Small. 2019; 15(38): e1903121.

85. Kongseng S, Yoovathaworn K, Wongprasert K, Chunhabundit R, Sukwong P, Pissuwan D. Cytotoxic and inflammatory responses of $\mathrm{TiO} 2$ nanoparticles on human peripheral blood mononuclear cells. J Appl Toxicol. 2016; 36: 1364-73.

86. Meng B, Yang X, Chen Y, Zhai J, Liang X. Effect of titanium particles on osteoclast activity in vitro. Mol Med Rep. 2010; 3(6):1065-9.

87. Souza JGS, Costa Oliveira BE, Bertolini M, et al. Titanium particles and ions favor dysbiosis in oral biofilms. J Periodontal Res. 2020; 55(2):258-266.

88. Suárez-López Del Amo F, Rudek I, Wagner VP, et al. Titanium Activates the DNA Damage Response Pathway in Oral Epithelial Cells: A Pilot Study. Int J Oral Maxillofac Implants. 2017; 32(6):1413-1420.

89. St Pierre CA, Chan M, Iwakura Y, Ayers DC, Kurt-Jones EA, Finberg RW. Periprosthetic osteolysis: characterizing the innate immune response to titanium wear-particles. J Orthop Res. 2010 Nov; 28(11):1418-24.

90. Sridhar S, Wang F, Wilson TG, Palmer K, Valderrama P, Rodrigues DC. The role of bacterial biofilm and mechanical forces in modulating dental implant failures. J Mech Behav Biomed Mater. 2019; 92:118-127.

91. Su YC. Modern oral implantology. Beijing: People's Medical Publishing House. 2004; p:64

92. Deppe H, Grünberg C, Thomas M, Sculean A, Benner KU, Bauer FJ. Surface morphology analysis of dental implants following insertion into bone using scanning electron microscopy: a pilot study. Clin Oral Implants Res. 2015; 26(11):1261-1266

93. Franchi M, Bacchelli B, Martini D, et al. Early detachment of titanium particles from various different surfaces of endosseous dental implants. Biomaterials. 2004; 25(12):2239-2246.

94. Schliephake H, Reiss G, Urban R, Neukam FW, Guckel S. Metal release from titanium fixtures during placement in the mandible: an experimental study. Int J Oral Maxillofac Surg 1993; 8: 502-11.

95. Aboushelib MN, Kleverlaan CJ, Feilzer AJ. Evaluation of a high fracture toughness composite ceramic for dental applications. J Prosthodont. 2008; 17(7):538-544.

96. Elias CN, Fernandes DJ, Resende CR, Roestel J. Mechanical properties, surface morphology and stability of a modified commercially pure high strength titanium alloy for dental implants. Dent Mater. 2015; 31(2): e1-e13.

97. Klotz MW, Taylor TD, Goldberg AJ. Wear at the titanium-zirconia implant-abutment interface: a pilot study. Int J Oral Maxillofac Implants. 2011; 26(5):970-975.

98. Tawse-Smith A, Ma S, Duncan WJ, Gray A, Reid MR, Rich AM. Implications of Wear at the Titanium-Zirconia Implant-Abutment Interface on the Health of Peri-implant Tissues. Int J Oral Maxillofac Implants. 2017; 32(3):599-609.

99. Alrabeah GO, Knowles JC, Petridis H. The effect of platform switching on the levels of metal ion release from different implant-abutment couples. Int J Oral Sci. 2016; 8(2):117-25.

100. Alrabeah GO, Knowles JC, Petridis H. Reduction of Tribocorrosion Products When Using the Platform-Switching Concept. J Dent Res. 2018; 97(9):995-1002.

101. Grenón MS, Robledo J, Ibáñez JC, Sánchez HJ. Titanium diffusion in shinbone of rats with osseointegrated implants. J Microsc. 2016 Nov; 264(2):182-188.

102. Cundy WJ, Mascarenhas AR, Antoniou G, Freeman BJ, Cundy PJ. Local and systemic metal ion release occurs intraoperatively during correction and instrumented spinal fusion for scoliosis. J Child Orthop. 2015; 9(1):39-43.

103. Cha JK, Paeng K, Jung UW, Choi SH, Sanz M, Sanz-Martín I. The effect of five mechanical instrumentation protocols on implant surface topography and roughness: A scanning electron microscope and confocal laser scanning microscope analysis. Clin Oral Implants Res. 2019; 30(6):578-587.

104. Eger M, Hiram-Bab S, Liron T, et al. Mechanism and Prevention of Titanium Particle-Induced Inflammation and Osteolysis. Front Immunol. 2018; 9:2963.

105. Smith MV, Lee MJ, Islam AS, et al. Inhibition of the PI3K-Akt signaling pathway reduces tumor necrosis factor-alpha production in response to titanium particles in vitro. J Bone Joint Surg Am. 2007; 89(5):1019-1027.

106. Annunziata M, Guida L. The Effect of Titanium Surface Modifications on Dental Implant Osseointegration. Front Oral Biol. 2015; 17:62-77.

107. von Walter M, Rüger M, Ragoss C, Steffens GC, Hollander DA, Paar O, et al. In vitro behavior of a porous $\mathrm{TiO} 2 /$ perlite composite and its surface modification with fibronectin. Biomaterials. 2005; 26(16):2813-26.

108. Saldaña L, Vilaboa N, Vallés G, González-Cabrero J, Munuera L. Osteoblast response to thermally oxidized Ti6Al4V alloy. J Biomed Mater Res A. 2005; 73(1):97-107.

109. Feng B, Weng J, Yang BC, Qu SX, Zhang XD. Characterization of surface oxide films on titanium and adhesion of osteoblast. Biomaterials 2003; 24:4663-70.

110. Li LH, Kong YM, Kim HW, Kim YW, Kim HE, Heo SJ, et al. Improved biological performance of $\mathrm{Ti}$ implants due to surface modification by micro-arc oxidation. Biomaterials 2004; 25:2867-75.

111. Vallés G, González-Melendi P, González-Carrasco JL, et al. Differential inflammatory macrophage response to rutile and titanium particles. Biomaterials. 2006; 27(30):5199-5211.

112. Li X, Huang $\mathrm{Q}$, Liu L, et al. Reduced inflammatory response by incorporating magnesium into porous $\mathrm{TiO} 2$ coating on titanium substrate. Colloids Surf B Biointerfaces. 2018; 171:276-284.

113. Boesch-Saadatmandi C, Wolffram S, Minihane AM, Rimbach G. Effect of apoE genotype and dietary quercetin on blood lipids and TNF-alpha levels in apoE3 and apoE4 targeted gene replacement mice. Br J Nutr. 2009; 101(10):1440-1443. 
114. Bischoff SC. Quercetin: potentials in the prevention and therapy of disease. Curr Opin Clin Nutr Metab Care. 2008; 11(6):733-740.

115. Zhang L, Tian Z, Li W, Wang X, Man Z, Sun S. Inhibitory effect of quercetin on titanium particle-induced endoplasmic reticulum stress (ERS)-related apoptosis and in vivo osteolysis. Biosci Rep. 2017; 37(4): BSR20170961.

116. Ziyan L, Yongmei Z, Nan Z, Ning T, Baolin L. Evaluation of the anti-inflammatory activity of luteolin in experimental animal models. Planta Med. 2007; 73(3):221-6

117. Shin DK, Kim MH, Lee SH, Kim TH, Kim SY. Inhibitory effects of luteolin on titanium particle-induced osteolysis in a mouse model. Acta Biomater. 2012; 8(9):3524-3531.

118. Li M, Wang W, Geng L, et al. Inhibition of RANKL-induced osteoclastogenesis through the suppression of the ERK signaling pathway by astragaloside IV and attenuation of titanium-particle-induced osteolysis. Int J Mol Med. 2015; 36(5):1335-1344. 